\title{
Genetic Variability, Correlation and Path Coefficient Analysis of Ethiopian Mustard (Brasica Carinata A.Braun) Genotypes
}

\author{
Fekadu Amsalu* \\ Holetta Agricultural Research Center, Addis Ababa, Ethiopia.
}

*Corresponding Author: Fekadu Amsalu, Holetta Agricultural Research Center, Addis Ababa, Ethiopia.

\begin{abstract}
The experiment was carried out to assess genetic variability, trait association and path coefficient analysis for Ethiopian mustard genotypes in order to select the desired plant types for high yield, oil and their components. The experiment was carried out in Randomized Complete Block Design in three replications at Holetta Agricultural Research Centre. The results of combined analysis indicated that studied traits of genotypes for yield and its related component traits were highly and significantly different for all traits compared. This revealed that there was a considerable magnitude of variability among the different genotypes for all the traits except for Seed yield per plant, number of secondary branches and plant height. In genetic variability, heritability and genetic advance analysis yield per plot (52432.72, 286770.34), oil yield (11754.25, 57297.33), number of seeds per plant (155.7286, 2611.72), days to flowering (21.62, 68.03) showed high phenotypic and genotypic variances, respectively indicating that the genotypes could be reflected by the phenotype and the effectiveness of selection based on the phenotypic performance for these traits. Oil $(33.30 \%)$, days to flowering (31.78\%), days to maturity (30.94\%), exhibited high heritability estimates. In genotypic correlation coefficients yield per plot showed significant and positive correlation with oil yield (0.971), seed yield per plant (0.825), date of maturity (0.588) and date of flowering (0.577) which indicates that taking into account these traits as selection parameter will be an effective way to increase seed yield, and oil yield. Analyzed value from genotypic coefficient of variation, heritability and genetic advance, correlation co-efficient and path coefficient, oil yield, seed yield per plant, date of flowering and maturity, number of seeds per plant, number of primary branches, plant height and number of secondary branches were the traits which could be considered for future mustard crop breeding program.
\end{abstract}

Keywords: Mustard, genetic variability, heritability, correlation, path analysis.

\section{INTRODUCTION}

The genus Brassica of Brassicaceae family as a whole is believed to have originated around the Mediterranean, Eastern Afghanistan and the adjoing portion of Pakistan and North-Eastern Africa (Hemigway, 1976). The genus includes six economically important species, namely, Brassica rapa, B. oleracea, B. nigra, B. juncea, B. napus, and B. carinata (Doweny and Röbbelen, 1989). Ethiopian mustard is believed to be originated in the highlands of the Ethiopian plateau and the adjoining portion of East Africa and the Mediterranean coast (Gomez-Campo and Prakash, 1999).The genus Brassica includes economically important species that provide oil for human consumption and raw materials for the industry, source as leaf and root vegetables and used for fodder and condiments (Getinet et al. 1991). Ethiopian mustard is important as source of oil and as a leafy vegetable in mid altitude and highland areas, (1700 to 2800 meters a.s.l). At its early stage of development the leaf is used as vegetable either by thinning or topping and seed can be also harvested from the same plant for oil extraction and other uses that include: greasing traditional bread baking clay pan (Mitad), curing certain ailments and preparing beverages (Alemayehu, 2001). In Ethiopia research on mustard started in the late 1960s by Ethiopian Institute of Agricultural Research with objective of developing highyielding mustard genotypes in increased of oil contents and meal quality. In doing so the breeding approaches for Ethiopian mustard improvement remained confined to selection and recombination followed by selection. To address this challenge for a better breeding program, it should have a broad genetic base. The success of any breeding program depends upon the genetic variability existed in the breeding material. The assessment of parameters including phenotypic and genotypic coefficients of variation, heritability in a broad sense, and genetic advance as a percent of the mean is a pre-requisite 
for making effective selection. The existing genetic base is not enough to meet the challenge. Seed yield is a complex character that can be determined by several components reflecting positive or negative effect upon this trait, whereas it is important to examine the contribution of each of the various components in order to give more attention to those having the greatest influence on seed yield (Marjanovic- Jeromela et al., 2007). Clear awareness of the association between yield and its component traits is paramount importance of making the best use of these relationships in selection. Determination of correlation coefficients is an important statistical procedure to evaluate breeding programs for high yield, as well as to examine direct and indirect contributions to yield variables (Ali et al., 2003). Path coefficient technique splits the correlation coefficients into direct and indirect effect i.e., alternative characters or pathways and thus permits a critical examination of components that influence a given correlation and can be helpful in formulating an efficient selection strategy (Sabaghnia et al., 2010). Therefore, correlation in combination with the path coefficient analysis quantifies the direct and indirect contribution of one character upon another (Dewey and Lu, 1959). Hence the present study was conducted to assess the genetic variability, trait association and path coefficient analysis for Ethiopian mustard genotypes in order to select desired plant types for high yield, oil and their component traits in central highlands of Ethiopia.

\section{Materials And Methods}

The experiment was conducted in experimental field at Holetta Agricultural Research Centre during 2007/08 cropping season. The test location, Holetta Agricultural Research Centre, is the main testing site for highland mustard varieties. It is believed to represent the major crop growing agro ecologies of Ethiopia in the highland areas. The centre is located $30 \mathrm{~km}$ south west of Addis Ababa at altitude of 2400 m.a.s.l. It received an average annual rainfall of $956 \mathrm{~mm}$. Annual temperature ranges $24.6^{\circ} \mathrm{c}$ to $-0.2^{\circ} \mathrm{c}$ minimum, is the typical of oil seed growing areas in the central high land. The soil type of the centre is luvisol /eutric nitosols with a good drainage system. The experiment was carried out to assess genetic variability, correlation and path analysis of Ethiopian mustard genotypes for seed yield, oil content and their component traits of ten genotypes of Ethiopian mustard against two standard checks (Yellow Dodolla and Holetta 1) and one cultivar as a local check. A seed rate of $10 \mathrm{~kg} / \mathrm{ha}$ was utilized to conduct the experiment. Planting was done on 19 June 2007. Two-hand weeding and fertilizer rate of 46/69 $\mathrm{N} / \mathrm{P}_{2} \mathrm{O}_{5} \mathrm{Kg} \mathrm{ha}^{-1}$ was the inputs of improved packages used for assessment purpose on each individual experimental plot. Randomized Complete Block Design with three replications was employed. The gross plot size was nine-meter square (six rows of 5meter long and $30 \mathrm{~cm}$ spacing) and the net harvest plot size was six-meter square (four central rows). The four central rows in each plot were used for data recording. By considering the central four rows the pre harvested agronomic data such as $50 \%$ date of flowering, 50\% and date of maturity was recorded. In addition to this plant height, number of primary branches and number of secondary branches of these characters per five plants were respectively collected. Besides pre harvested data post harvest agronomic data such as number of seeds per five plants was counted by seed counter machine, seed yield which was obtained from the central four rows, oil content that was measured by using Nuclear Magnetic Resonance spectroscope, oil yield that was also obtained by multiplying seed yield with corresponding oil percentage and thousand seed weight which was obtained by weighing counted thousand seeds using seed counter machine and were taken and statistically analysed using SAS soft ware. Major criteria during the assessment considered were yield and oil production enhancing component traits. In this experiment ten genotypes of Ethiopian mustard were randomly taken from different stages of mustard trial that were evaluated for the previous season and stocked at Holetta Agricultural Research Centre to represent the available germplasm /breeding stock. These genotypes were originally acquired from the Institute of Biodiversity conservation of Ethiopia and were randomly collections from different regions of Ethiopia.

\section{RESUltS AND DisCUSSION}

The results of combined analysis of mean squares of variance are presented in Table 1. The result indicated that studied traits of genotypes for seed yield and its related component traits were highly and significantly different for seed yield, oil content and oil yield, date of flowering, date of maturity, primary branches, number of seeds per plant and thousand seed weight. This revealed that there was a considerable magnitude of variability among the different genotypes for all the traits compared. Similar findings were reported by Amsalu et al., 2017, Yared 2010, Abebe 2006. The high amount of 
genetic variability in the studied genotypes for the major yield contributing traits along with oil content and oil yield indicated that the possibility of further improvement of these traits. Yadava, 1996 reported similar findings pertaining to the presence of high genetic variability for different traits including seed yield/plant.

Table1. The Mean Squares for Different Sources of Variation and the Corresponding Coefficient of Variation In Percent for the Eleven Traits Studied.

\begin{tabular}{|c|c|c|c|c|}
\hline Traits & Replication(2) & Genotype (12) & Error (24) & CV \\
\hline Seed yield & 395862.538 & $222034.248^{* *}$ & 64736.094 & 11.02 \\
\hline Oil content & 0.002309 & $4.98^{* *}$ & 0.002308 & 0.12 \\
\hline Oil yield & 68213.1026 & $46280.0342^{* *}$ & 11017 & 11.08 \\
\hline Seed yield per plant & 33.88 & $11.50^{*}$ & 36.07 & 13.86 \\
\hline Date of flowering & 5.15 & $66.44^{* *}$ & 1.59 & 1.58 \\
\hline Date of maturity & 0.17 & $24.74^{* *}$ & 0.92 & 0.53 \\
\hline Primary branch & 1.25 & $2.17^{* *}$ & 0.53 & 7.76 \\
\hline Secondary branch & 52.61 & $13.10^{*}$ & 13.03 & 18.55 \\
\hline Plant height & 152.6 & $107.35^{*}$ & 96.47 & 2.58 \\
\hline Number of seeds & 1130956.8 & $344817.41^{* *}$ & 654173.57 & 14.84 \\
\hline Thousand seed weight & 0.21 & $0.279^{* *}$ & 0.07 & 6.04 \\
\hline
\end{tabular}

** Indicate significance at 0.01 probability level; ns, non significant, figures in parenthesis refer to degrees of freedom, CV: Coefficient of variation.

Mean performance of thirteen Ethiopian mustard genotypes for eleven traits:

As indicated in table 2 significant variations were observed among the genotype for days to flowering and days to maturity. Days to flowering ranged from 74 to 89 , days to maturity from 175 to 184 and plant height from 186 to $208 \mathrm{~cm}$. The high yielding genotypes, PGRC/E 208585, PGRC/E 208528/2, PGRC/E 208556 were 89, 85, 82 days in flowering and maturity dates 184, 184 and 181 respectively. The late flowering date and maturity date was for the highest yielding genotype 89 and 184 days respectively. The mean average number of primary branches of the tested genotypes ranges from 8 (for PGRC/E21369/1/2) to 11 (for PGRC/E 208585 and PGRC/E208524). On the other side number of secondary branches also ranges from 8 (for PGRC/E21369/1/2, PGRC/E 21369/1/4 and PGRC/E 21176) to 15 (for PGRC/E 208585). Over all among the tested genotypes the highest number of primary branches and number of secondary branches 11 and 15 was observed respectively for the genotype PGRC/E 208585. As shown in table 2 the tested genotypes, PGRC/E 208585, PGRC/E 208528/2 and PGRC/E 208556 in seed yield and oil yield are first, second and third respectively. In addition seven genotypes (PGRC/E208585, PGRC/E208528/2, PGRC/E208556, PGRC/E21369/1/2, PGRC/E21176/1/1, PGRC/E 21369/1/1 and PGRC/E208524) gave the highest seed yield over the mean of the standard checks respectively. Among the tested genotypes except PGRC/E 20112/1 all genotypes including the standard checks gave the highest seed yield above the local check genotype and the lowest yield was for PGRC/E 20112/1(1.90t/ha). The yield range was 1.90 t/ha (PGRC/E 20112/1) to 2.77 t/ha (PGRC/E 208585). Oil content ranges from 39.6 \% (PGRC/E 208585/1) to 43.7 $\%$ (PGRC/E 208524). In oil content aspect only one genotype (PGRC/E 208524) gave the highest oil content percent, i.e., $43.7 \%$ from all tested genotypes and standard checks. The oil yield ranges from $0.77 \mathrm{t} / \mathrm{ha}$ (PGRC/E 20112/1) to 1.16 t/ha (PGRC/E 208585) and almost one variety (PGRC/E 20112/1) gave comparable seed yield with local check. The number of seeds per plants was highest for the genotype PGRC/E 208524 (3347) and it ranges in number from 2124 (PGRC/E 21176/1/1) to 3347 (PGRC/E 208524). In thousand seed weight Holetta -1 gave the highest thousand seed weight $(5.0 \mathrm{gm})$ from all tested genotypes. It also ranges from 4.0gm (for PGRC/E 208585 and PGRC/E 20112/1) to 5.0 gm (Holetta-1).

Table2. Mean Performance of Thirteen Genotypes of Ethiopian Mustard for Eleven Different Traits Studied at Holetta Agricultural Research Centre During 2007/08 Cropping Season.

\begin{tabular}{|c|c|c|c|c|c|c|c|c|c|c|c|c|c|}
\hline \multirow[b]{2}{*}{$\begin{array}{c}\mathrm{N} \\
\mathrm{O}\end{array}$} & \multirow{2}{*}{\multicolumn{2}{|c|}{ Genotype }} & \multirow{2}{*}{$\begin{array}{c}\text { See } \\
d \\
\text { yiel } \\
d \\
t / h a\end{array}$} & \multirow{2}{*}{$\begin{array}{c}\text { Oil } \\
\text { conte } \\
\text { nt } \\
\%\end{array}$} & \multirow{2}{*}{$\begin{array}{c}\text { Oil } \\
\text { yiel } \\
d \\
\text { t/ha }\end{array}$} & \multirow{2}{*}{$\begin{array}{l}\text { Seed } \\
\text { yield } \\
\text { per } \\
\text { plant }\end{array}$} & \multicolumn{2}{|c|}{ Days to } & \multirow{2}{*}{$\begin{array}{c}\text { Prima } \\
\text { ry } \\
\text { branc } \\
\mathrm{h}\end{array}$} & \multirow{2}{*}{$\begin{array}{l}\text { Second } \\
\text { ary } \\
\text { branch }\end{array}$} & \multirow{2}{*}{$\begin{array}{c}\text { Plan } \\
\text { t } \\
\text { heig } \\
\text { ht }\end{array}$} & \multirow[t]{2}{*}{ NS } & \multirow[t]{2}{*}{ Tsw } \\
\hline & & & & & & & $\begin{array}{c}\text { floweri } \\
\text { ng }\end{array}$ & $\begin{array}{c}\text { Maturi } \\
\text { ty }\end{array}$ & & & & & \\
\hline 1 & 1.1.1.1.1.1.1.1 & $P G$ & 2.3 & 39.7 & 0.9 & 10.4 & 77 & 178 & 9 & 9 & 197 & 241 & 4.3 \\
\hline
\end{tabular}


Genetic Variability, Correlation and Path Coefficient Analysis of Ethiopian Mustard (Brasica Carinata A.Braun) Genotypes

\begin{tabular}{|c|c|c|c|c|c|c|c|c|c|c|c|c|}
\hline & RC/E 21369/1/1 & 2 & & 2 & & & & & & & 8 & \\
\hline 2 & PGRC/E 21369/1/2 & 2.37 & 39.9 & 0.94 & 13.8 & 75 & 177 & 8 & 8 & 208 & $\begin{array}{c}306 \\
8\end{array}$ & 4.4 \\
\hline 3 & PGRC/E 21369/1/4 & 2.15 & 40.2 & 0.86 & 11.5 & 77 & 178 & 9 & 8 & 186 & $\begin{array}{c}268 \\
4 \\
\end{array}$ & 4.3 \\
\hline 4 & PGRC/E 20112/1 & 1.90 & 40.4 & 0.77 & 11.0 & 85 & 183 & 10 & 9 & 198 & $\begin{array}{c}279 \\
0\end{array}$ & 4.0 \\
\hline 5 & PGRC/E 208585/1 & 2.12 & 39.6 & 0.84 & 11.9 & 79 & 179 & 9 & 10 & 202 & $\begin{array}{c}268 \\
8\end{array}$ & 4.5 \\
\hline 6 & PGRC/E 208556 & 2.58 & 41.3 & 1.07 & 11.3 & 82 & 181 & 9 & 9 & 202 & $\begin{array}{c}272 \\
3\end{array}$ & 4.1 \\
\hline 7 & PGRC/E 21176/1/1 & 2.36 & 41.5 & 0.98 & 9.3 & 82 & 180 & 9 & 8 & 207 & $\begin{array}{c}212 \\
4\end{array}$ & 4.3 \\
\hline 8 & PGRC/E 208528/2 & 2.74 & 41.1 & 1.13 & 12.5 & 85 & 184 & 9 & 7 & 206 & $\begin{array}{c}300 \\
4\end{array}$ & 4.2 \\
\hline 9 & PGRC/E 208524 & 2.24 & 43.7 & 0.98 & 14.8 & 80 & 177 & 11 & 13 & 202 & $\begin{array}{c}334 \\
7\end{array}$ & 4.4 \\
\hline 10 & PGRC/E 208585 & 2.77 & 41.7 & 1.16 & 12.3 & 89 & 184 & 11 & 15 & 207 & $\begin{array}{c}308 \\
3\end{array}$ & 4.0 \\
\hline 11 & Yellow Dodolla & 2.41 & 43.5 & 1.05 & 11.9 & 80 & 181 & 10 & 9 & 208 & $\begin{array}{c}253 \\
8\end{array}$ & 4.9 \\
\hline 12 & Holetta-1 & 2.05 & 40.9 & 0.84 & 12.3 & 74 & 177 & 9 & 9 & 202 & $\begin{array}{c}238 \\
0\end{array}$ & 5.0 \\
\hline 13 & Local check & 1.99 & 40.5 & 0.81 & 11.7 & 74 & 175 & 9 & 9 & 204 & $\begin{array}{c}249 \\
6\end{array}$ & 4.7 \\
\hline & Mean & 2.31 & 41.1 & 0.95 & 11.9 & 80 & 179 & 9 & 9 & 202 & $\begin{array}{c}271 \\
9\end{array}$ & 4.4 \\
\hline & $\mathrm{CV}(\%)$ & 11.0 & 2.43 & 11.9 & $\begin{array}{c}13.8 \\
6\end{array}$ & 1.58 & 0.54 & 7.8 & 5.75 & $\begin{array}{c}4.8 \\
6\end{array}$ & 3.73 & $\begin{array}{c}6.0 \\
5\end{array}$ \\
\hline & LSD $(5 \%)$ & 0.36 & 1.40 & 0.16 & 4.28 & 1.76 & 1.34 & 13.7 & 5.0 & $\begin{array}{c}13.7 \\
2 \\
\end{array}$ & $\begin{array}{c}1129 \\
.9 \\
\end{array}$ & $\begin{array}{c}0.3 \\
7 \\
\end{array}$ \\
\hline
\end{tabular}

NS: number of seeds, TSW: thousand seed weight.

\subsection{Genetic Variability, Heritability and Genetic Advance}

Estimates of genotypic and phenotypic variances, genotypic coefficient of variation (GCV), phenotypic coefficients of variation (PCV), heritability in broad sense, expected genetic advances and genetic advances as percent mean are given in Table3. Estimated genetic variance ranged from $0.023 \%$ for secondary branches to 52432.72 for seed yield per plot. Likewise phenotypic variance ranged from $0.35 \%$ for thousand seed weight to $286770.34 \%$ for seed yield $\mathrm{kg} / \mathrm{ha}$. Phenotypic coefficients of variation ranged from $2.83 \%$ Date of maturity to $56.80 \%$ for secondary branches. Genotypic coefficients of variation ranged from $0.94 \%$ for plant height to $11.45 \%$ for oil yield per plot. Seed yield per plot $(52432.72,286770.34)$, oil yield $(11754.25,57297.33)$, number of seeds per plant $(155.7286,2611.72)$ and days to flowering $(21.62,68.03)$ showed high phenotypic and genotypic variances, respectively indicating that the genotypes could be reflected by the phenotype and the effectiveness of selection based on the phenotypic performance for these traits. Likewise, Amsalu et al., 2017 and Abebe(2006) reported high genotypic and phenotypic variance for seed yield and oil content in Ethiopian mustard.

Low genotypic variance was recorded for traits such as secondary branches $(0.023)$ and thousand seed weight (0.069667). However, high genotypic coefficients of variation (GCV) and phenotypic coefficients of variation (PCV) were shown in traits such as oil yield per plot $(11.45,25.27)$ seed yield per plant(11.38,35.19) respectively, which means selection of these traits based on phenotype characteristics may be useful for oil yield and seed yield per plants improvement program. This result agrees with the findings of Yared(2006),Abebe (2006) and Aytac and Kinaci (2009).

\subsection{Heritability in the Broad Sense}

Breeders can make rapid progress where heritability is high by using selection methods that are dependant solely on phenotypic characteristics (e.g. mass selection). However, where heritability is 
low methods of selection based on families and progeny testing are more effective and efficient. Heritability estimated using the total genetic variance is called broad sense heritability .Heritability in the broad sense of the traits is presented in Table 3 In this study, heritability values were found to be sufficiently high for most important yield component characters. Dabholkar (1992) generally classified heritability estimates as low (5-10\%), medium (10-30\%) and high (30-60\%). Based on this classification, oil content $(33.30 \%)$, days to flowering (31.78\%), days to maturity (30.94\%), exhibited high heritability estimates. Oil content was found to be the most heritable trait in the studied genotypes, with heritability of $33.30 \%$, followed by days to flowering $(31.78 \%$ ) and maturity (30.94\%). This indicates that selection for these traits in the genotype would be most effective for the expression of these traits in the succeeding generations. Therefore, good improvement can be made if some of these traits are considered as selection criteria in future breeding program. Similar findings had been reported by Yared (2010) for oil content of seeds, date of flowering and date of maturity. High heritability value for oil content of seeds, date of flowering and date of maturity recorded in the current study was also recorded by Yared(2010)and Abebe(2006).According to Singh(1993), if the heritability of a character is high, selection for such character is fairly easy as selected character will be transmitted to its progeny. This is because there would be a close correspondence between the genotype and phenotype due to a relatively similar contribution of the environment to the genotype. On the other hand oil yield (20.52), primary branches per plant $(20.25 \%)$, seed yield (18.28\%), seed yield per plant $(10.46 \%)$ and number of seeds per plants $(5.963 \%)$ exhibit medium heritability estimates.

\subsection{Genetic Advance}

Concerning the genetic advance at 5\% intensity the highest genetic gain was predicted for seed yield per plot (201.68kg) followed oil yield (101.18kg), date of flowering (5.4) and while the lowest genetic advance was predicted for secondary branches per plant $(0.01 \%)$. Genetic advance as a percent mean ranged from $0.10 \%$ for secondary branches per plant to $43.73 \%$ for oil content (Table 3). Within this range, a relatively high genetic advance as a percent mean was observed for oil content $(43.73 \%$ )and oil yield $(10.58 \%)$ followed by seed yield per plot $(8.74 \%)$. On the other hand, the lowest genetic gain as percent of means was observed for secondary branches $(0.10) \%$ ) followed by plant eight $(0.26 \%)$. Low genetic advance as percent means observations in this study indicates that characters probably were under environmental influence than the genotypic expression and that selection based on these traits would be ineffective.

Table3. Estimates of Mean Performance, Range, Genetic Variance (GV), Phenotypic Variance (PV), Genotypic Coefficient of Variation (GCV), Phenotypic Coefficient of Variation (PCV), Heritability and Genetic Advance (GA) in Different Genotypes of Ethiopian Mustard.

\begin{tabular}{|c|c|c|c|c|c|c|c|c|c|}
\hline Studied traits & $\begin{array}{c}\text { Mean } \\
\pm \text { S.E(m) }\end{array}$ & Range & GV & PV & GCV & PCV & H(bs) & GA & $\begin{array}{c}\text { GA } \\
\text { as }\end{array}$ \\
\hline Seed yield & $2308 \pm 58.141$ & $\begin{array}{c}1.90- \\
27.70\end{array}$ & 52432.72 & 286770.34 & 9.92 & 23.21 & 18.28 & 201.68 & 8.74 \\
\hline Oil content & $41.0 \pm 0.201$ & $\begin{array}{c}39.6- \\
43.7\end{array}$ & 1.66 & 4.98 & 3.14 & 5.44 & 33.30 & 1.53 & 43.73 \\
\hline Oil yield & $947 \pm 25.401$ & $\begin{array}{c}0.77- \\
1.13\end{array}$ & 11754.25 & 57297.33 & 11.45 & 25.27 & 20.52 & 101.18 & 10.58 \\
\hline $\begin{array}{c}\text { Seed yield per } \\
\text { plant }\end{array}$ & $12 \pm 0.530$ & $\begin{array}{c}2124- \\
3347\end{array}$ & 1.83 & 17.51 & 11.38 & 35.19 & 10.46 & 0.90 & 7.51 \\
\hline $\begin{array}{c}\text { Date of } \\
\text { flowering }\end{array}$ & $80 \pm 0.756$ & $74-89$ & 21.62 & 68.03 & 5.81 & 10.31 & 31.78 & 5.4 & 6.75 \\
\hline $\begin{array}{c}\text { Date of } \\
\text { maturity }\end{array}$ & $179 \pm 0.464$ & $\begin{array}{c}175- \\
184\end{array}$ & 7.94 & 25.66 & 1.57 & 2.83 & 30.94 & 3.23 & 1.80 \\
\hline $\begin{array}{c}\text { Primary } \\
\text { branch }\end{array}$ & $9 \pm 0.167$ & $8-11$ & 0.55 & 2.70 & 8.24 & 18.26 & 20.37 & 0.69 & 7.62 \\
\hline $\begin{array}{c}\text { Secondary } \\
\text { branch }\end{array}$ & $9 \pm 0.623$ & $8-15$ & 0.023 & 26.13 & 1.69 & 56.80 & 0.09 & 0.01 & 0.10 \\
\hline $\begin{array}{c}\text { Plant height } \\
\text { Nant }\end{array}$ & $202 \pm 1.624$ & $186-$ & 3.63 & 203.82 & 0.94 & 7.07 & 1.78 & 0.52 & 0.26 \\
\hline Number of & $763 \pm 122.116$ & $2124-$ & 155.7286 & 2611.72 & 1.64 & 6.70 & 5.963 & 6.28 & 0.82 \\
\hline
\end{tabular}




\begin{tabular}{|c|c|c|c|c|c|c|c|c|c|}
\hline seeds & & 3068 & & & & & & & \\
\hline Thousand & $4.4 \pm 0.061$ & $4.0-$ & 0.069667 & 0.35 & 6.00 & 13.45 & 19.90 & 0.26 & 5.53 \\
seed weight & & 5.0 & & & & & & & \\
\hline
\end{tabular}

\subsection{Correlation Coefficient for Ethiopian Mustard Tested Genotypes of Traits}

Genotypic correlation coefficients among yield and its component traits are presented in (table 4). Seed yield per plot showed highly significant and positive correlation with oil yield (r: 0.971), seed yield per plant (r: 0.825), significant with maturity (r: 0.588) and date of flowering(r: 0.577) which indicates that taking into account oil yield, seed yield per plant, flowering and maturity date as selection parameter will be an effective way to increase seed, and oil yield. This result is in agreement with the findings of Abebe (2006), Aytac and Kinaci (2009) and Jeromela et al. (2007) who reported positive correlation of seed yield per plot with oil yield per plot and seed yield per plant. Oil content percent showed highly and positively correlated association with number of seeds per plant (r: 0.728) and primary branches per plant(r: 0.692) and seed yield per plants also showed highly and positively association with oil yield (r: 0.971), seed yield(r: 0.825) and positive significant correlation with date of flowering (r: 0.577) and date of maturity (r: 0.588). Date of flowering showed positive significant correlation for all studied traits except oil content, secondary branches, plant height and negative significant correlation with thousand seed weight: (r: -0.707). Similarly date of maturity showed positive significant association and negative correlation with above mentioned traits. Primary branches per plants showed highly significant positive correlation with oil content (r: 0.692), secondary branches per plant (r: 0.820) and number of seeds (r: 0.718). Secondary branches per plants showed highly significant positive correlation with primary branches per plant (r: 0.820) and significant positive correlation with number of seeds per plant (r: 0.562). Hence making simultaneous increase for these characters with yield per plot, oil content and oil yield is difficult. From these results, we may extract that indirect selection for earliness for days to maturity; shortness of plant height will be worthwhile in improvement of the seed and oil yield. Result of positive correlation of days to flowering with days to maturity of these two traits with seed yield per plant and oil yield are in agreement with the result of Abebe (2006) and Yared (2010). Association of plant height with all studied traits showed positive non significant correlation.

Table4. Genotypic Correlation Coefficients for Combination of 11 Traits in Studied Ethiopian Mustard Genotypes.

\begin{tabular}{|c|c|c|c|c|c|c|c|c|c|c|c|}
\hline & Sy & Oc & Oy & sypl & $\mathrm{df}$ & $\mathrm{Dm}$ & $\operatorname{Pr}$ & $\mathrm{Sb}$ & ph & Ns & Tsw \\
\hline Sy & 1.000 & $0.301 \mathrm{~ns}$ & $0.971 * *$ & $0.298^{*}$ & $0.577^{*}$ & $0.588^{*}$ & $0.148 \mathrm{~ns}$ & $0.209 \mathrm{~ns}$ & $0.443 \mathrm{~ns}$ & $0.455 \mathrm{~ns}$ & $\begin{array}{c}- \\
0.387 \mathrm{~ns}\end{array}$ \\
\hline $\mathrm{oc}$ & $0.301 \mathrm{~ns}$ & 1.000 & $0.516 \mathrm{~ns}$ & $0.301 \mathrm{~ns}$ & $0.309 \mathrm{~ns}$ & $0.1817 \mathrm{~ns}$ & $0.692 * *$ & $0.419 \mathrm{~ns}$ & $0.373 \mathrm{~ns}$ & $0.728 * *$ & $0.186 \mathrm{~ns}$ \\
\hline oy & $0.971 * *$ & $0.517 \mathrm{~ns}$ & 1.000 & $0.971 * *$ & $0.608^{*}$ & $0.587 *$ & $0.314 \mathrm{~ns}$ & $0.299 \mathrm{~ns}$ & $0.495 \mathrm{~ns}$ & $0.594 *$ & $\begin{array}{c}- \\
0.305 \mathrm{~ns}\end{array}$ \\
\hline sypl & $0.825 * *$ & $0.301 \mathrm{~ns}$ & $0.971 * *$ & 1.000 & $0.577 *$ & $0.588 *$ & $0.1483 \mathrm{~ns}$ & $0.209 \mathrm{~ns}$ & $0.443 \mathrm{~ns}$ & $0.826^{* *}$ & $\begin{array}{c}-\overline{-} \\
0.387 \mathrm{~ns}\end{array}$ \\
\hline$\overline{\mathrm{df}}$ & $0.578^{*}$ & $0.3087 \mathrm{~ns}$ & $0.608^{*}$ & $0.577 *$ & 1.000 & $0.925 * *$ & $0.590^{*}$ & $0.409 \mathrm{~ns}$ & $0.228 \mathrm{~ns}$ & $0.565^{*}$ & $0.707 * *$ \\
\hline $\mathrm{dm}$ & $0.588^{*}$ & $0.182 \mathrm{~ns}$ & $0.587 *$ & $0.588 *$ & $0.925 * *$ & 1.000 & $0.373 \mathrm{~ns}$ & $0.141 \mathrm{~ns}$ & $0.21 \mathrm{~ns}$ & $0.468 \mathrm{~ns}$ & $-0.588 *$ \\
\hline $\mathrm{pr}$ & $0.148 \mathrm{~ns}$ & $0.692 * *$ & $0.314 \mathrm{~ns}$ & $0.148 \mathrm{~ns}$ & $0.590^{*}$ & $0.373 \mathrm{~ns}$ & 1.000 & $0.820 * *$ & $0.077 \mathrm{~ns}$ & $0.718 * *$ & $\begin{array}{c}- \\
0.201 \mathrm{~ns} \\
\end{array}$ \\
\hline $\mathrm{sb}$ & $0.209 \mathrm{~ns}$ & $0.419 \mathrm{~ns}$ & $0.299 \mathrm{~ns}$ & $0.209 \mathrm{~ns}$ & $0.409 \mathrm{~ns}$ & $0.142 \mathrm{~ns}$ & $0.820 * *$ & 1.000 & $0.162 \mathrm{~ns}$ & $0.562 *$ & $\begin{array}{c}- \\
0.205 \mathrm{~ns}\end{array}$ \\
\hline $\mathrm{ph}$ & $0.442 \mathrm{~ns}$ & $0.373 \mathrm{~ns}$ & $0.495 \mathrm{~ns}$ & $0.443 \mathrm{~ns}$ & $0.228 \mathrm{~ns}$ & $0.216 \mathrm{~ns}$ & $0.077 \mathrm{~ns}$ & $0.162 \mathrm{~ns}$ & 1.000 & $0.180 \mathrm{~ns}$ & $0.176 \mathrm{~ns}$ \\
\hline Ns & $0.455 \mathrm{~ns}$ & $0.728 * *$ & $0.594 *$ & $0.455 \mathrm{~ns}$ & $0.565^{*}$ & $0.468 \mathrm{~ns}$ & $0.718 * *$ & $0.562 *$ & $0.180 \mathrm{~ns}$ & 1.000 & $\begin{array}{c}- \\
0.151 \mathrm{~ns}\end{array}$ \\
\hline Tsw & $-0.387 n s$ & $0.186 n s$ & $\overline{0.305 \mathrm{~ns}}$ & $-0.387 \mathrm{~ns}$ & $-0.707 * *$ & $-0.588 *$ & $-0.201 \mathrm{~ns}$ & $-0.201 \mathrm{~ns}$ & $0.176 \mathrm{~ns}$ & $\overline{0.151 \mathrm{~ns}}$ & 1.000 \\
\hline
\end{tabular}

Sy: seed yield, Oc : Oil content, oy: oil yield, SYPPL: seed yield per plant, df, date of flowering, Dm: Date of maturity, $\mathrm{Pb}$ : primary branch, $\mathrm{Sb}$ : secondary branch, $\mathrm{Ph}$ : plant height, ns: number of seeds, tsw: thousand seed weight.

\subsection{Genotypic Path Coefficient Analysis}

Association of traits determined by correlation coefficient may not provide the exact picture of the relative importance of direct and indirect influence of each yield component traits on yield. 
Correlation coefficients were partitioned into direct and indirect effect to find out a clear picture of the inter-relationship between yield and other yield related traits by using path analysis. The results of path coefficient analysis for studied traits were indicated in table 5. Path coefficient analysis showed that the oil yield had highest positive direct effect on seed yield per plot (3.341). It had positive indirect effect on seed yield, i.e., seed yield per plants(3.067),followed by date of flowering(1.877), date of maturity(1.674), number of seeds per plant(1.539),oil content(1.007),plant height(0.850) primary branches/plant $(0.613)$, thousand seed weight $(0.537)$, secondary branches $(0.491)$. Finally it made highly significant positive correlation with seed yield per plant and seed yield per plot ( $\mathrm{rg}=$ $0.971^{* *}$ ). The genotypic correlation of seed yield per plot and seed yield per plant was positive and considerably higher in magnitude. It is mainly due to high positive direct effect and positive indirect effects of other traits. Therefore, selection would be effective for number of seed yield per plant and oil yield. Ara, 2010 found number of siliquae/plant had the highest positive direct effect on seed yield similar to the present findings. Seed yield per plant had positive direct effect on seed yield per plot (3.157) and positive indirect effect on oil yield (3.245), on date of flowering(1.782), date of maturity(1.679), number of seeds per plant(1.178),plant height(0.761),thousand seed weight $(0.682)$,oil content $(0.586)$,secondary branches per plants $(0.344)$ and primary branches per plant $(0.290)$. It was observed high positive direct effects on seed yield per plot $\left(\mathrm{rg}=0.825^{* *}\right)$. Date of flowering had positive direct effect on seed yield per plot (3.086) and positive indirect effect on seed yield by date of maturity (2.658) followed by oil yield (2.032), seed yield per plant (1.823) number of seeds per plant (1.462), thousand seed weight (1.246), Number of primary branches per plant (1.153), secondary branches per plant (0.673), oil content (0.602) and plant height (0.392). Date of maturity had positive direct effect on seed yield per plot (2.853) and positive indirect effect on date of flowering(2.853) followed by oil yield (1.960), seed yield per plant(1.858), number of seeds per plant (1.212), thousand seed weight (1.035), number of primary branches per plant(0.729), plant height(0.370)and oil content (0.354) and secondary branches per plant(0.233). Finally, it had significant positive genotypic correlation with seed yield plot $\left(\mathrm{rg}=0.588^{*}\right)$. Mahmud, 2008 also found the highest direct effects on seed yield per plant of Brassica spp for number of primary branches per plant. Number of primary branches per plant had positive direct effect on seed yield per plot (1.954) and positive indirect effect on number of seeds per plant(1.859), date of flowering(1.821),secondary branches per plant(1.349), oil content (1.348), date of maturity(1.064), oil yield(1.049), seed yield per plant $(0.468)$, thousand seed weight $(0.355)$ and plant height(0.132). Secondary branches per plant showed the highest positive direct effect (1.644)and positive indirect effect on number of primary branches(1.602),number of seeds per plant(1.456),date of flowering(1.264),oil content(1.197)oil yield(0.998) seed yield per plants(0.661), date of maturity $(0.404)$, thousand seed weight $(0.353)$ and plant height (0.278). Plant height had positive direct effect on seed yield per plot (1.718) and positive indirect effect on oil yield(1.652), seed yield per plant(1.398), oil content(1.064), date of flowering(0.704), date of maturity(0.615),number of seeds per plant(0.466),secondary branches(0.266)and primary branches $(0.150)$. It had also negative indirect effect on thousand seed weight (-0.353). Number of seeds per plant had positive direct effect on seed yield per plot(2.590) and positive indirect effect on oil yield(1.985) followed by date of flowering(1.742), seed yield per plants(1.436), primary per branches(1.402), oil content(1.251), secondary branches (0.924), plant height $(0.3 .09)$ and thousand seed weight $(0.266)$. Thousand seed weight had a negative direct effect ($1.762)$ on seed yield per plot and positive indirect effect on oil content $(0.482)$ followed by plant height (0.303).on other hand thousand seed weight had highest negative indirect effect on days to flowering (-2.181), date of days to maturity (-1.676), seed yield per plant (-1.222), oil yield (-1.017), primary branches $(-0.393)$ and number of seeds per plant $(-0.390)$. It was observed to have high positive in direct effects on oil content (0.482) and plant height (0.3.3) but its influence was invalidate by the negative indirect effects with days to flowering $(-2.181)$, date of days to maturity $(-1.676)$, seed yield per plant (-1.222), oil yield (-1.017), number of seeds per plant $(-0.390)$ and primary branches ($0.330)$ which resulted non-significant negative correlation with seed yield per plot ( $\mathrm{rg}=-0.387)$.

The path coefficient analysis indicated that oil yield, seed yield per plant, date of flowering, date of maturity, number of seeds per plant, number of primary branches, plant height and number of secondary branches were the most important contributors to seed yield per plot which could be taken in to consideration for future breeding program. Wide variability has been found among the 
genotypes for all the traits. The result of the study will provide the ability of breeders to develop desirable plant types having high seed yield, oil content and oil yield with early maturity. Analyzed value from genotypic coefficient of variation, heritability and genetic advance in percent of mean, correlation co-efficient and even path coefficient indicates oil content, oil yield, seed yield per plant, date of flowering, date of maturity, number of seeds per plant, number of primary branches, plant height and number of secondary branches were the such traits which could be considered for future mustard crop breeding program.

Table5. Genotypic Path Coefficient Analysis Showing Direct (Bold) and Indirect Effects of Different Traits in Ethiopian Mustard Genotype

\begin{tabular}{|c|c|c|c|c|c|c|c|c|c|c|c|}
\hline & OC & OY & SYPPL & DF & DM & PB & SB & PH & NS & TSW & SY \\
\hline OC & $\mathbf{1 . 9 5 0}$ & 1.725 & 0.949 & 0.953 & 0.518 & 1.351 & 0.690 & 0.640 & 1.885 & -0.328 & $0.301 \mathrm{~ns}$ \\
\hline OY & 1.007 & $\mathbf{3 . 3 4 1}$ & 3.067 & 1.877 & 1.674 & 0.613 & 0.491 & 0.850 & 1.539 & 0.537 & $0.971^{* *}$ \\
\hline SYPPL & 0.586 & 3.245 & $\mathbf{3 . 1 5 7}$ & 1.782 & 1.679 & 0.290 & 0.344 & 0.761 & 1.178 & 0.682 & $0.825^{* *}$ \\
\hline DF & 0.602 & 2.032 & 1.823 & $\mathbf{3 . 0 8 6}$ & 2.658 & 1.153 & 0.673 & 0.392 & 1.462 & 1.246 & $0.578^{*}$ \\
\hline DM & 0.354 & 1.960 & 1.858 & 2.853 & $\mathbf{2 . 8 5 3}$ & 0.729 & 0.233 & 0.370 & 1.212 & 1.035 & $0.588^{*}$ \\
\hline PB & 1.348 & 1.049 & 0.468 & 1.821 & 1.064 & $\mathbf{1 . 9 5 4}$ & 1.349 & 0.132 & 1.859 & 0.355 & $0.148 \mathrm{~ns}$ \\
\hline SB & 1.197 & 0.998 & 0.661 & 1.264 & 0.404 & 1.602 & $\mathbf{1 . 6 4 4}$ & 0.278 & 1.456 & 0.353 & $0.209 \mathrm{~ns}$ \\
\hline PH & 1.064 & 1.652 & 1.398 & 0.704 & 0.615 & 0.150 & 0.266 & $\mathbf{1 . 7 1 8}$ & 0.466 & -0.353 & $0.442 \mathrm{~ns}$ \\
\hline NS & 1.251 & 1.985 & 1.436 & 1.742 & 1.336 & 1.402 & 0.924 & 0.309 & $\mathbf{2 . 5 9 0}$ & 0.266 & $0.455 \mathrm{~ns}$ \\
\hline TSW & & & & & & & & & & & - \\
& 0.482 & -1.017 & -1.222 & -2.181 & -1.676 & -0.393 & -0.330 & 0.303 & -0.390 & $\mathbf{- 1 . 7 6 2}$ & $0.387 \mathrm{~ns}$ \\
\hline
\end{tabular}

Sy: seed yield, Oc: Oil content, OY: oil yield, SYPPL: seed yield per plant, DF, Date of flowering, DM: Date of maturity, PB: primary branch, SB: secondary branch, PH: plant height, ns: number of seeds, TSW: thousand seed weight.

\section{CONCLUSION}

The present study was carried out to assess the genetic variability, trait association and path coefficient analysis for Ethiopian mustard genotypes which are very important for an effective breeding program to select desired plant types to meet the arising demand for high seed yield, oil content and their component traits in central highlands of Ethiopia. Studied traits of genotypes for seed yield and its related component traits were highly and significantly different for seed yield, oil content and oil yield, date of flowering, date of maturity, primary branches, number of seeds per plant and thousand seed weight. This revealed that the presence of a considerable magnitude of variability among the different genotypes of Ethiopian mustard for all the traits except for Seed yield per plant, number of secondary branches and plant height.

The high amount of genetic variability in the studied genotypes for the major yield contributing traits along with oil content and oil yield indicated that the existing possibility for the further improvement of these traits. Phenotypic correlation coefficients were higher in magnitude than their respective genotypic correlation coefficients for most of the traits indicating the environmental influence on phenotypic expression. In genotypic correlation coefficients analysis Seed yield per plot showed highly significant and positive correlation with oil yield, seed yield per plant, significant with date of maturity and date of flowering which indicates that taking into account oil yield, seed yield per plant, flowering date, maturity date, as selection parameter will be an effective way to increase seed, and oil yield.The path coefficient analysis indicated that oil yield, seed yield per plant, date of flowering, date of maturity, number of seeds per plant, number of primary branches, plant height and number of secondary branches were the most important contributors to seed yield per plot which could be taken in consideration for future breeding program. Wide variability has been found among the genotypes for all the characters. The result of the study will provide the ability of breeders to develop desirable plant types having high seed yield and oil yield with early maturity. Analyzed value from genotypic coefficient of variation, heritability and genetic advance in percent of mean, correlation co-efficient and even path coefficient, oil yield, seed yield per plant, date of flowering, date of maturity, number of seeds per plant, number of primary branches, plant height and number of secondary branches were the such traits which could be considered for future mustard crop breeding program. 


\section{REFERENCES}

[1] Abebe Delesa. 2006. Genetic Variability and Association among Seed Yield and Yield Related Traits in Ethiopian mustard (Brassica carinata A. Braun) at Kulumsa, Arsi. An M.Sc. Thesis Presented to the School of Graduate Studies of Alemaya University. 75p.

[2] Adefris Teklewold. 2005. Diversity Study Based on Quality Traits and RAPD Markers and Investigation of Heterosis in Ethiopian Mustard. Ph.D. diss. Georg-August Univ. of Göttingen, Germany. 161p.

[3] Ali, N., F. Javidfar, J.Y. Elmira and M.Y. Mirza. 2003. Relationship among yield components and selection criteria for yield improvement in winter rapeseed (Brassica napus L.).Pak. J. Bot. 35(2): 167174 .

[4] Amsalu F, Sentayehu A, Bulecha W (2017). Genetic Variability, Heritability,Genetic advance, Genetic advance as Percent Mean and Character Association of Ethiopian Mustard (Brasica carinata A. Braun) Land races. International Journal of Plant Breeding and Crop Science, 4(1): 166-177.

[5] Ara, S. 2010. Variability, Correlation and Path Coefficient in segregating population of Brassica rapa obtained through inter varietal crosses. M.S. thesis, Sher-e-Bangla Agricultural University, Department of Genetics and Plant Breeding, Dhaka, Bangladesh. Pp.46-51.

[6] Aytaç, Z. and G. Kınac. 2009. Genetic variability and association studies of some quantitative characters in winter rapeseed(Brassica napus L.). African Journal of Biotechnology, 8 (15): 35473554.Dabholkar, A.R. 1992. Elements of biometrical genetics. Concept Publishing Company, New Delhi, India.431p.

[7] Doweny R.K. and G. RÖbbelen. 1989. Brassica Species. In RÖbbelen G, Doweny RK and Ahri A (eds) Oil crops of the world. McGraw-Hill New York. pp. 339-359

[8] Fekadu Amsalu, Sentayehu Alamerew. Bulecha Woyessa.2017.International Journal of Plant Breeding and Crop Science Vol.4 (1), pp.166-177, March, 2017.www. Premier publishers. org. ISSN: 2167-0449

[9] Getinet, A. and A. Nigussie. 1991. Highland Oil Crops: a two decade research experience in Ethiopia. Research report No. 30. Institute of Agricultural Research, Addis Ababa, Ethiopia. 30p.

[10] Giriraji, K. and S. Vijayakumar. 1974. Path coefficient analysis of yield attributes in mung bean. Ind. J. Genet. 34: 27-30

[11] Gomez-Campo, C. and S. Prakash. 1999. Origin and domestication of the Brassica. pp. 33-58. In: GomezCampo C (ed.). Biology of Brassica Coenospecies. Elsevier, Amsterdam.

[12] Hemingway, J.S. 1976. Mustards Brassica species and Sinapsis alba (Cruciferae). In: Evolution of Crop Plants. N.W. Simmounds (ed.) Longan. London. 339p.

[13] Jeromela, A.M., R. Marinkovic, A. Mijic, M. Jankulovska and Z. Zdunic. 2007. Interrelationship between oil Yield and Other Quantitative Traits in Rapeseed (Brassica napus L.). J. Central Eur. Agric. 8(2): $165-170$

[14] Mahmud, M.A.A. 2008. Intergenotypic variability study in advanced lines of Brassica rapa. M.S. thesis, Sher-e-Bangla Agricultural University, Department of Genetics and Plant Breeding, Dhaka, Bangladesh. Pp.40-69.

[15] Nigussie, A. and H. Becker. 2001. Variation and inheritance of erucic acid content in Brassica carinata germplasm collections from Ethiopia. Plant Breeding, 120: 33 1-335

[16] Röbbelen, G. and W. Thies. 1980. Biosynthesis of oil and breeding for improved oil quality of rapeseed. pp. 253-278. In: Tsunoda, K.H. and Gomez-Campo, C. (eds.). Brassica crops and Wild Allies. Japan Scientific Society press, Tokyo.

[17] SAS Institute INC., 2002- 2008. SAS*STAT, users guide, version 9.2, Cary N.C., SAS INC

[18] Yadav, Y. P. and S. Hari. 1996. Morpho-physiological determinants of yield under water stress condition in Indian mustard (Brassica juncea (L.) Czern and Coss.). Acta Horticulturea 407: 155-160

[19] Yared Semahegn. 2010. Genetic diversity and Relationship among Association amongEthiopian mustard (Brassica carinata A. Braun) genotypes based on their agronomic and quality Traits in at Holetta Agricultural research,. An M.Sc. Thesis Presented to the School of Graduate Studies of JimaUniversity, 75 p.

Citation: Fekadu Amsalu, "Genetic Variability, Correlation and Path Coefficient Analysis of Ethiopian Mustard (Brasica Carinata A.Braun) Genotypes” International Journal of Research Studies in Agricultural Sciences (IJRSAS), 2020; 6(3), pp. 17-25, http://dx.doi.org/10.20431/2454-6224.0603003

Copyright: () 2020 Authors. This is an open-access article distributed under the terms of the Creative Commons Attribution License, which permits unrestricted use, distribution, and reproduction in any medium, provided the original author and source are credited. 